\title{
3D Braille as Media in Improving Tooth Brushing Skill for Blind Children
}

\author{
Fastabiqul Hanif $^{1 *}$, Lanny Sunarjo ${ }^{2}$, Bedjo Santoso ${ }^{3}$, Masrifan Djamil $^{4}$, Ari Suwondo ${ }^{5}$ Dyah Fatmasari $^{6}$ \\ 1, 2, 3,4, 5, 6 Poltekkes Kemenkes Semarang, Dental Therapist and Hygienist, \\ Tirto Agung Rd., Semarang Jawa Tengah 50268, Indonesia
}

\begin{abstract}
The problem experienced by blind children is that difficult to do self-activity especially in behavioral dental and oral health care. One of the behavioral change strategies for blind children is through dental and oral health education with counseling activities which should put attention to the characteristics of the blind child as well as utilize the hearing and touch senses by implementing 3D Braille Media. It is a development of $3 \mathrm{D}$ printing media comprising procedure of proper tooth brushing. The aim of this research is to create 3D Braille as a media of learning to improve tooth brushing skills for blind children. We implemented Research and Development ( $R$ \& D) method which has five stages of research: data collection, design and build, expert validation, model test and model result. It's performed in the Quasy experiment pre-test and post-test with control group design sample divided into 2 groups, of which 15 blind children were in intervention group using 3D Braille media and 15 blind children were in control group using Braille flipcharts. The data used intraclass corellation coeffiecient test, paired and independent sample test. The results show that 3D Braille is worthy of a learning media about tooth brushing with p-value of 0.000. Besides, it is more effective in improving tooth brushing skills with p-value of 0.002 , as well as lowering the index debris with p-value of 0.020 . According to the results of the research, it can be inferred that the impementation of 3D Braille Media model is more effective in improving the tooth brushing skills and lowering the index debris compared to Braille flipcharts.
\end{abstract}

Keywords:- 3d Braille, Blind Children, Tooth Brushing Skills.

\section{INTRODUCTION}

Children with blindless have a high level of caries and poor oral and dental hygiene compared to normal children [1][2]. The prevalence of caries in blind children in the world, one which stands high is in India with $60 \%$ percentage. Nevertheless, in Indonesia, the caries prevalence reach more up to $80.6 \%[3][4]$. Not to mention, the prevalence of dental and oral hygiene in blind children in India is $40 \%$, while Indonesia strikes to $50 \%$ [5]. Globally, dental caries has a higher impact on quality of life due to pain in the oral cavity and reduction of oral cavity function for communication and as a tool for digestion. The more the number of teeth lost, the lesser the cognitive and memory function. Chronic caries is known to affect the nutritional status, growth and weight of children[6]. More than 50 million hours per year are lost due to children are often absent for school because of dental and oral health problems. This makes the intellectual level of the child decreases if it continues lead for a long time[7].

Daily tooth brushing behavior in normal children in Indonesia is $94.7 \%$ yet the proper toothbrushing percentage is only $2.8 \%$. Meanwhile the daily tooth brushing behavior in Central Java, Indonesia is $94.6 \%$, but in contrast, the proper brushing teeth behavior is just $1.7 \%$.[8].

Based on the results of a preliminary study in one of SLB (Special Education School) in Indonesia precisely in Jepara regency, Central Java, as much as $40 \%$ of tooth brushing activities are carried out by blind children in the morning or in the afternoon bathing. The blind children who like cariogenic food is $73 \%$ and proper tooth brushing technique percentage is only $7 \%$.

Either clinical or non-clinical factors can influence the caries of permanent tooth. One of the most dominant contributing factors is behavior and OHI-S (Oral Hygiene Index Simplified). Therefore, a plan for overcoming the problem is by promotive and preventive activities[9]. Efforts to improve the degree of dental and oral hygiene of blind children is on behavioral change, because behavior is a factor that affects awareness in taking care of dental and oral hygiene. Knowledge influences dental and oral hygiene, attitude as well as skills. In addition, it also affect the status of dental and oral hygiene. Behavior change strategies is in form of strength, law, and education[10][11].

One of the behavioral change strategies for blind children through dental and oral health education is with counseling activities. However, the method has to be adjusted with respect to the condition of blind children. Children with blindness have limited sense of sight so it is difficult to recognize an object visually in the learning process. Blind children rely on the sensitivity of the sense of touch. The way to utilize their sense of touch is by using braille letters. Braille is a tactile writing system used for blind children. Traditionally, these letters have been embossed on paper. The blind know and easily understand braille writing because they are accustomed of reading braille writing. This makes dental and oral health education more easily accepted[12][13].

Braille media has been applied in Indonesia to improve the dental and oral hygiene. Nevertheless, the media only introduces letters to blind children so that they are less able 
to recognize the whole object of picture. The recognition of braille arising picture, allows blind children to feel the shape of objects and recognize visual picture quickly so that it helps the development of tactile sharpness and mobility of children as well as their feeling to sense and feel the ambience[14][15].

According to the background and problem, a 3D braille becomes an urge to be created in order to improve the skill of toothbrushing in blind children. It is a development of 3D Printing media where procedures of proper brushing are provided to stimulate the attention, interests, thoughts and feelings of blind children to begin improving their tooth brushing skills. 3D braille media model trains the hands and mind coordination of blind children besides reading dental and oral hygiene messages on it. Also, there are 3D printed-object so that what they read is conveyed through these picture-object.

\section{METHODOLOGY}

The research methodology is Research and Development (R\&D), which is used to produce a product and test the effectiveness of it. The Research and Development (R\&D) procedure consists of 5 main steps, namely data collection, design and build, expert validation and revision, model test, and model results[17].

The research design was quasy experiment (pre and post-test with control group design). This research was carried out in SLBN (State Special Education School) Semarang, Indonesia as an intervention group and SLBN (State Special Education School) Jepara, Indonesia as a control group. The sampling technique was purposive sampling with 30 children divided into two groups, 15 children in each intervention group and the control group. Research data using ratio scale. Intraclass correlation statistical test was implemented to determine the feasibility of the model, while the normality test used the Shapiro Wilk test regarding the number of respondents is less than 50. The effectivity test on the paired group normal data used dependent sample test and for the unpaired group, it used the independent sample test.

\section{RESULTS AND DISCUSSION}

\section{A. Data Collection}

The results of data collection conducted through interview method and Systematica Literature Review concluded that to improve the skill of tooth brushing in blind children, it needs learning method and media adapted to the characteristics of blind children by utilizing the senses of hearing and touch.

\section{B. Design and Build}

The result from data collection is used to produce the model design. The results of information revealed that blind children cannot independently take care of their dental and oral hygiene. So the researchers made a 3D Braille media model with respect to the needs of method and learning media for blind children as replication based on Notoadmojo, Maher and Roger's theories.

\section{Expert Validation}

\begin{tabular}{|c|c|c|c|}
\hline \multicolumn{4}{|c|}{ Expert Validation } \\
\hline & $\mathbf{n}$ & $\mathrm{f}(\%)$ & $p$-value \\
\hline Relevant & 10 & 100 & 0,000 \\
\hline Irrelevant & 0 & 0 & \\
\hline
\end{tabular}

* Intraclass correlation coefficient

Table 1:- $3 \mathrm{~d}$ braille Statistical test validation from the expert

Table 1 show the 3D braille statistical test validation from the expert which indicates the p-value score is in 0.000 , which means that the $3 \mathrm{D}$ Braille model is relevant and suitable as a media to improve the skill of tootbrushing in blind children.

\section{Model Test}

\begin{tabular}{|c|c|c|c|}
\hline \multirow{2}{*}{ No } & Variable & \multicolumn{2}{c|}{-value $^{*}$} \\
\cline { 3 - 4 } & \multicolumn{3}{|c|}{ Blind children $(\mathbf{n}=\mathbf{1 5})$} \\
\hline \multirow{3}{*}{} & Pre-test skill & 0,960 & 0,331 \\
\cline { 2 - 4 } & Post-test skill & 0,930 & 0,363 \\
\cline { 2 - 4 } & Pre-test debri index & 0,150 & 0,880 \\
\cline { 2 - 4 } & Post-test debri index & 0,140 & 0,721 \\
\hline
\end{tabular}

*Shapiro-wilk

Table 2:- Data Normality Test For Blind Children

Table 2 shows the data normality test for blind children as the respondents. Normality test results show that the $\mathrm{p}$ value is more than 0.05 , so it wrapped that the data are normally distributed so it can be continued using the parametric test.

\begin{tabular}{|c|c|c|c|c|c|}
\hline Variable & & \multicolumn{4}{|c|}{ Paired test * } \\
\hline & & $\mathrm{n}$ & Mean \pm SD & Delta & P-Value \\
\hline \multicolumn{6}{|l|}{ Skill } \\
\hline Intervention & Pre & 15 & $11,80 \pm 2,908$ & \multirow{2}{*}{5,67} & \multirow{2}{*}{0,000} \\
\hline & Post & 15 & $17,47 \pm 2,200$ & & \\
\hline \multirow[t]{2}{*}{ Control } & Pre & 15 & $11,13 \pm 1,995$ & \multirow{2}{*}{3,14} & \multirow{2}{*}{0,000} \\
\hline & Post & 15 & $14,27 \pm 2,815$ & & \\
\hline \multicolumn{6}{|l|}{ Debris Index } \\
\hline Intervention & Pre & 15 & $1,907 \pm 4,509$ & \multirow{2}{*}{1,01} & \multirow{2}{*}{0,000} \\
\hline & Post & 15 & $0,893 \pm 5,132$ & & \\
\hline \multirow[t]{2}{*}{ Control } & Pre & 15 & $2,113 \pm 1,528$ & \multirow{2}{*}{0,75} & \multirow{2}{*}{0,000} \\
\hline & Post & 15 & $1,360 \pm 2,000$ & & \\
\hline
\end{tabular}

*paired sample test

Table 3:- Paired-Data Effectivity Test

Table 3 shows theh paired-data effectivity test. The effectivity of the data test on the skill of tooth bruhsing in blind children show that the p-value of the intervention group is 0.000 which is less than 0.05 , meaning that the $3 \mathrm{D}$ braille media model is effective in increasing the skill of tooth brushing. The p-value of the control group is 0.000 (p $<0.05$ ), meaning that the braille flipchart media and tooth brushing demonstration are effective in improving the brushing skills of blind children. 
Same results also occur on the effectivity test of debris index, which show that the $\mathrm{p}$-value of the intervention group is 0.000 , in which p-value is less than 0.05 , meaning that the $3 \mathrm{D}$ braille media model effectively reduces the debri index. The $\mathrm{p}$-value of the control group is 0.000 ( $\mathrm{p}<0.05$ ), representing that the flipchart braille media and tooth brushing demonstration are effective in reducing the debris index of blind children.

\begin{tabular}{|c|c|c|c|c|}
\hline Variabel & \multicolumn{4}{|c|}{ Unpaired-data test * } \\
\hline Skill & $\mathrm{n}$ & Mean \pm SD & Delta & P-Value \\
\hline Intervention & 15 & & & \\
\hline Control & 15 & $14,47 \pm 2,200$ & \multirow{2}{*}{3,20} & \multirow{2}{*}{0,002} \\
\cline { 1 - 3 } Debris Index & & & & \\
\hline Intervention & 15 & $0,840 \pm 0,462$ & \multirow{2}{*}{0,52} & \multirow{2}{*}{0,020} \\
\cline { 1 - 3 } Control & 15 & $1,360 \pm, 0,674$ & & \\
\hline
\end{tabular}

*Independent sampel test

Table 4:- non-paired data effectivity test

Table 4 shows the non-paired data effectivity test. The effectivity test on the skill of toothbrushing of blind children show that the p-value is 0.002 ( $\mathrm{p}<0.05)$, meaning that the $3 \mathrm{D}$ braille media model is more effective in increasing brushing skill compared to flipchart braille media and tooth brushing demonstration.

The effectivity test on debris index for blind children shows that the $p$-value is $0.020(p<0.05)$, meaning that the $3 \mathrm{D}$ braille media model is more effective in reducing debris index for blind children compared to flipchart braille media and tooth brushing demonstration.

\section{E. Model Result}

The result of the model is $3 \mathrm{D}$ braille media which is the outcome from the development of counseling method and innovative media for tooth brushing by exploiting the senses of hearing and touch and in accordance with the characteristics of blind children regarding the implementation of 3D braille media model guided by the school teachers.
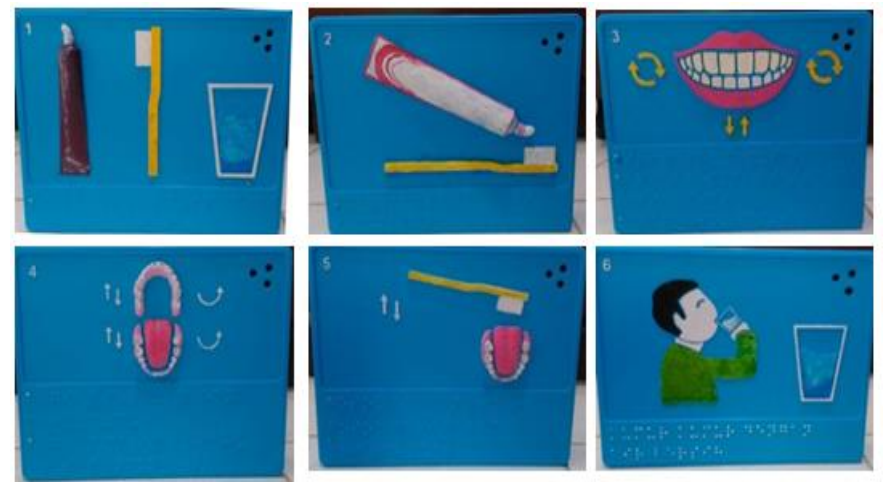

\section{DISCUSSION}

3D braille media model was performed to blind children in addition to learning media as well as to improve the skill of toothbrushing and reduce the debris index. The skill of tooth brushing has increased because 3D braille media have many advantages. There are stimuli, triggering thoughts, attractiveness, creativity that makes them understand their brushing skill because the media take the role of blind children in terms of hearing and touching senses. In the learning process, the education was carried out 10 minutes before the learning hours in small groups according to their respective classes. The children are directly involved demonstrating on how to brush their teeth properly. This is consistent with the theory of StimulusOrganism-Response (SOR) behavior change which states that behavior change depends on the stimulus or stimulus provided.

Blind children could express their motivation in this learning method, besides, small group discussion was more effective in improving dental and oral hygiene compared to large group[18], as well as the implementation of toothbrushing was also implemented on day 1 to 10 (2 weeks). The practice of brushing was done in the school yard according to the group. Each group was accompanied by their class teacher. In the second week, the children began to show changes on their way to brush their teeth. A child's direct involvement, in fact, can improve tooth brushing skill[19]. Stage by stage has made a significant change in the intervention group because to change a person's habit, it requires a constant period. Steady learning on toothbrushing will change someone's behavior better[20].

The debris index of blind children has decreased because the sample has been taught to understand the practice of brushing the teeth properly. Correct and proper tooth brushing practices can get rid of plaque and debris[21]. The practice of proper tooth brushing will improve the dental and oral hygiene of blind children[22]. Basically, the intelligence ability of a blind child is the same as a normal child. Yet, if the skill of tooth brushing in blind child is lacking, it will affect their own dental and oral hygiene.

The 3D braille model is stated to have succeeded in changing the habit of toothbrushing in blind children. It can be seen because 10 days afterwards, the blind child continued to brush their teeth after school break and the blind children are able to do it properly. Consequently, the debri index is decreased. The success of $3 \mathrm{D}$ braille is due to the fact that the implementation has been carried out for 10 days to provide more stimulus in the learning process by involving the teacher in guiding and assisting children in brushing their teeth.

Fig 1:- 3D Braille Media 


\section{CONCLUSION}

3D Printing development triggers the idea of this research in 3D Braille model for dental and oral hygiene learning for Special Education School's students, particularly blind children. Adapting the senses of hearing and touching, 3D Braille model successfully proven that it is more effective in improving the toothrushing skill of preschool children than another same method with flipchart without feature of voice indicating the picture-object message.

\section{REFERENCES}

[1]. Kemenkes, "Child health care guidelines in schools are excellent (SLB)," 2010.

[2]. M. Jain, S. P. Bharadwaj, L. S. Kaira, D. Chopra, D. Prabu, and S. Kulkarni, Oral Health Status and Treatment Need Among Institutionalised HearingImpaired and Blind Children and Young Adults in Udaipur , India . A Comparative Study," A comparative Study OHDM 2014.

[3]. M. Choirunnisa, P. Agusmawanti, and M. Yusuf, "Fones To Decrease Dental Plaque Index In Children With Blind Age 6-13 Years In Semarang," Odonto Dental Journal, 2015, vol. 2, pp. 36-40.

[4]. BE Marimbun, CN Mintjelungan, DHC Pengemanan, "Knowledge level relationships on dental and oral health with dental caries status in the visually impaired" vol. 4, pp. 0-5, Jurnal e-Gigi,2016.

[5]. D. Agnintia, F Rachmawati,R Arsita, PL Berti, " Quality Self Care And Home Care Solution Dental Health and mouth blind child at Sdlb A-Ykab Surakarta," Odonto Dental Journal, 2013.

[6]. A. Hamid, D. Wijaya, Z. Sulaiman, and I. Ismalayani, "Quality of life children aged 3-5 years with Early Chilhood Caries unhandled," J. Kesehat. Gigi,2019,vol. 6, no. 1, p. 14.

[7]. B. Santoso, N. Gejir, and D. Fatmasari, "Information System Monitoring Model Implemented in School Health Dental Unit,"ARC Journal of Dental Science, 2017, vol. 2, no. 4, pp. 8-11,.

[8]. Riskesdas, "Riskesdas Main Results 2018," http://www.depkes.go.id/article/view/18110200003/po tret-sehat-indonesia dari-riskesdas-2018.html.

[9]. L Sunarjo, Salikun, PW Ningrum "Factors causing high numbers of dental caries remained on elementary school students 02 Banjarsari District Talun District of Pekalongan Regency," Jounal ARSA, 2016, vol.1, pp. 22-28,

[10]. B Sutomo , B Santoso, NA Maula "Influence of parents 'behaviour on the Status of children's dental hygiene at SDN 03 Karangjati," J. Kesehat. Gigi, 2017, vol. 04, no. 2, pp. 21-26.

[11]. I. Wiradona, B. Widjanarko, and B. M. Syamsulhuda, "Influence of tooth brushing behaviour on dental plaque in grade IV and V students at SDN. Gajahmungkur District of Semarang," Health Promotion Journals,2016,vol. 8, no. 1, pp. 59-68,
[12]. E. Mardiati, Salikun, and K. Aprianti, "the Effectiveness of Audio Media and Braille Leaflet Media on the Knowledge of Maintaining Oral Hygiene Among Blind Children," J. Kesehat. Gigi,2018, vol. 5, no. 1, p. 61,

[13]. T. Mahantesha, A. Nara, P. R. Kumari, P. K. N. Halemani, V. Buddiga, and S. Mythri, “A comparative evaluation of oral hygiene using Braille and audio instructions among institutionalized visually impaired children aged between 6 years and 20 years: A 3monthfollow-up study.," J. Int. Soc. Prev. Community Dent., 2015, vol. 5, no. Suppl 2, pp. S129-32.

[14]. D Fatmasari, FM Sabilillah, RZ Tafzani, Y Sopianah, "Effect Of Braille Education (DBE) On Oral Hygiene In Child Blind Preface", J. Kesehat. Gigi, 2016,vol. 03, no. 2,

[15]. A. Stangl, J. Kim, and T. Yeh, "3D printed tactile picture books for children with visual impairments: A design probe," ACM Int. Conf. Proceeding Ser, 2014, no. June, pp. 321-324,.

[16]. M Sugiyono, Research and Development (R\&D).Bandung: Alfabeta, 2015.

[17]. M. Siskawati, P. Pargito, P. Pujiati, "Development of Monopoly learning Media to increase learning interest in student geography," J. Stud. Sos,2016 vol. 4, no. 1, pp. 72-80,.

[18]. D Fatmasari, YR Ramadhani, EA Ekoningtyas, T Wiyatini, "Salivary Glucose Level Increases Severity Of Periodontal Condition In Patients With Type 2 DM" Public Health Journals of Unnes," 2019, vol. 8, no. 1 , pp. $178-184$,.

[19]. C. Ganss, N. Schlueter, S. Preiss, and J. Klimek, "Tooth brushing habits in uninstructed adults Frequency, technique, duration and force," Clin. Oral Investig., vol. 13, no. 2, pp. 203-208, 2009.

[20]. F. Schwendicke, A. M. Jäger, S. Paris, L. Y. Hsu, and Y. K. Tu, "Treating pit-and-fissure caries: A systematic review and network meta-analysis," $J$. Dent. Res., vol. 94, no. 4, pp. 522-533, 2015.

[21]. M. R. Bishop, A. L. Kenzer, C. M. Coffman, C. M. Tarbox, J. Tarbox, and T. M. Lanagan, "Using stimulus fading without escape extinction to increase compliance with toothbrushing in children with autism," 2013, Res. Autism Spectr. Disord., vol. 7, no. 6, pp. 680-686.

[22]. H. Y. Liu, CC Chen, WC Hu, RC Tang, CC Chen, Tsai CC, ST Huang., "The impact of dietary and tooth-brushing habits to dental caries of special school children with disability," 2010, Res. Dev. Disabil., vol. 31 , no. 6 , pp. 1160-1169. 